\title{
KAJIAN FEMINISME DAN NILAI PENDIDIKAN DALAM NOVEL CINTA DI UJUNG SAJADAH KARYA ASMA NADIA
}

\author{
Nurul Kasanah \\ SDN Kebonsari I Tuban \\ Jln. Gajah mada No 20 Tuban \\ Tlp. 082333860118 \\ Email Nurulkasanah78@gmail.com
}

\begin{abstract}
Abstrak : Penelitian ini berlatar belakang dari keinginan peneliti untuk menemukan eksistensinya terkadang dipandang sebagai bentuk perlawanan. Apalagi oleh kaum patriarkis yang menempatkan kaum perempuan berada pada kedudukan dibawahnya atau sebagai pemandangan yang sedap dan panoramic belaka. Tujuan penelitian ini adalah untuk mendiskripsikan dan menjelaskan: (1) eksistensi perempuan yang terdapat dalam Novel Cinta di Ujung Sajadah Karya Asma Nadia.; (2) pokok-pokok pikiran feminism; dan (3) nilai-nilaipendidikan dalam gambaran feminism dan nilai pendidikan. Data yang sudah terkumpul dianalisis dengan teknik analisis model analisis interaktif dengan tiga alur kegiatan, (1) reduksi data, (2) penyajian data, dan (3) penarikan kesimpulan atau verifikasi. Hasil penelitian ini sebagai berikut: (1) eksistensi perempuan yang terdapat dalam novel Cinta di Ujung Sajadah Karya Asma Nadia ; (2) pokok-pokok pikiran feminisme, meliputi: kemandirian tokoh perempuan dan feminism social dalam novel; dan (4) nilai-nilai pendidikan dalam novel Cinta di Ujung Sajadah KaryaAsma Nadia antara lain: nilai agama, nilai moral, nilai sosial, dan nilai budaya.
\end{abstract}

Kata kunci: Novel Cinta di Ujung Sajadah, Kajian Feminisme, Nilai Pendidikan

\begin{abstract}
This study background of the desire of researchers to discover its existence is sometimes seen as a form of resistance. Moreover, by the patriarchal sees women are in position underneath or as a hearty and panoramic views of the sheerThe purpose of this study is to describe and explain: (1) the existence of women contained in the Novel of Love at the End Sajadah KaryaAsma Nadia .; (2) The basic thoughts of feminism; and (3) the value of education in the description of feminism and educational value. Data that has been analyzed by interactive analysis model analysis techniques with three grooves activities (1) data reduction, (2) presentation of data, and (3) conclusion or verification. The results of this study as follows: (1) the existence of women contained in the novel Love at the End of mat work is Asma Nadia; (2) The basic thoughts of feminism, including: independence of women and feminism social character in the novel; and (4) the value of education in the novel Love at the End of mat work is Asma Nadia among others: religious values, moral values, social values, and cultural values.
\end{abstract}

Keywords: Novel of Love at the End Sajadah, Feminism Studies, Values Education 


\section{PENDAHULUAN}

Perempuan merupakan objek yang selalu menarik untuk dibicarakan. Perempuan merupakan sumber inspirasi yang tak akan lekang oleh waktu. Perempuan sebagai objek citraan yang manis. Perempuan seperti sosok yangmempunyai dua sisi. Di satu sisi, perempuan adalah keindahan. perempuan dipujadan dimanjakan. Pesonanya dapat membuat laki-laki tergila-gila hingga berkenan melakukan apapun demi seorang perempuan. Tetapi di sisi lain, perempuan merupakan sosok yang lemah. Perempuan identik sebagai kaum yang terjajah. Perempuan sering tidak diberi kesempatan untuk membuat keputusan tertentu, mereka tergantung kepada lakilaki.

Hal tersebut di atas merupakan gambaran kebudayaan di Indonesia yangmasih memperlihatkan secara jelas keberpihakannya kepada kaum lakilaki.Salah satunya kebudayaan Jawa yang menempatkan perempuan sebagai yang kedua. Hal tersebut tercermin dalam ungkapan-ungkapan yang sangat meninggikan derajat laki-laki, misalnya wanita yang berarti wani ditata atau berani dan bersedia ditata atau diatur dan swarga nunut neraka katut yang berarti bahwa kebahagiaan atau penderitaan istri hanya tergantung pada suami merupakan contoh ketiadaan peran perempuan dalam keluarga.

Ketiadaan peran perempuan tidak hanya sebatas di lingkungan keluarga. Di lingkungan masyarakat juga terdapat anggapan bahwa perempuan merupakan kelas masyarakat yang sering diabaikan keberadaannya. Perempuan yangmencoba untuk bekerja di masyarakat juga sering kurang mendapat penghargaan. Perempuan pekerja sering diperlakukan tidak adil oleh atasan atau pemilik usaha.

Hal di atas merupakan gambaran bahwa sebagian besar masyarakat
Indonesia menganut sistem patriarki. Dalam sistem patriarki ini hubungan antara laki-laki dan perempuan bersifat hierarkis, yaitu kaum laki-laki berada dalam kedudukan puncak dan mendominasi kaum perempuan, sedangkan kaum perempuan berada pada kedudukan di bawahnya atau subordinat. Sistem patriarki ini tentu saja sangat merugikan kaum perempuan.

Keinginan perempuan untuk menemukan eksistensinya terkadang dipandang sebagai bentuk "Perlawanan". Apalagi oleh kaum patriarkis yang menempatkan kaum perempuan berada pada kedudukan di bawahnya atau sebagai pemandangan yang sedap dan panoramik belaka (Endraswara, 2011: 145). Padahal perempuan sebenarnya hanya ingin menemukan jati dirinya, membentuk, dan mengembangkan kesadaran bahwa ada potensi nonfisik yang harus dikembangkan dalam eksistensi dirinya sebagai manusia.

Kelemahan perempuan ini sering dijadikan alasan bagi laki-laki jahat untuk mengeksploitasi keindahannya. Perempuan dimanfaatkan kecantikannya untuk memuaskan nafsu dan mata lakilaki. Tubuh perempuan telah dijadikan objek komersial seksual. Perempuan juga tidak mempunyai otonomi.

Fenomena komersialisasi seksual perempuan sering ditemui dalam dunia sastra. Banyak novel-novel dan cerpencerpen yang menggambarkan kecantikan seorang tokoh perempuan menjadi sesuatu yang penting. Banyak pengarang yang menceritakan perempuan sebagai tokoh cantik yang diperebutkan laki-laki untuk keperluan pemenuhan nafsu semata-mata.

Kedudukan perempuan selalu dipandang lebih rendah daripada lakilaki, sehingga mereka dianggap sebagai the second sex, atau warga kelas dua. Bahkan dari segi religi juga diceritakan 
bahwa dalam rangka mengatur masyarakat, wahyu diturunkan pada jenis laki-laki. Inilah legitimasi pertama kelompok Adam, yang secara psikologis dan sosiologis mengkerangkakan polapola pikiran manusia untuk menempatkan laki-laki sebagai pusat. Legitimasi kedua diturunkan melalui mitologi Hawa yang berasal dari tulang rusuk Adam. Legitimasi ketiga juga ditujukan terhadap Hawa. Ia dinyatakan tidak memiliki iman yang kuat sehingga ia terpaksa memetik dan memakan buah kehidupan yang kemudian diikuti oleh Adam, perbuatan yang sesungguhnya dilarang oleh Tuhan (Ratna, 2011: 182). Perempuan dengan kelemahan-kelemahannya secara biologis selalu ditempatkan sebagai inferior atau kaum yang tertindas.

Gambaran kehidupan di atas mendorong adanya gerakan feminisme. Perjuangan feminisme sebenarnya tidak bertujuan untuk mengungguli atau mendominasi kaum laki-laki. Meskipun perempuan diidentifikasikan dengan kelas proletar atau kelas yang tertindas, dan kaum laki-laki disamakan dengan kaum borjuis atau kelas penindas, gerakan perempuan pada umumnya tidak bermaksud membalas dendam dengan menindas atau menguasai laki-laki. Feminisme memperjuangkan dua hal yang selama ini tidak dimiliki kaum perempuan pada umumnya, yaitu persamaan derajat mereka dengan lakilaki dan otonomi untuk menentukan apa yang baik bagi dirinya.

Gerakan feminisme ini juga sangat mempengaruhi dunia ilmu. Parafeminis terpelajar berusaha membebaskan perempuan dari berbagai penindasandan pembatasan di dunia ilmu. Salah satu upaya mereka adalah menjadikan perempuan sebagai bahan studi. Maka munculah kajian perempuan di berbagai program studi. Kajian ini bertujuan menambah pengetahuan pembaca tentang pengalaman, kepentingan dan kehidupan perempuan.

Di satu sisi terdapat sejumlah karya sastra tertentu, yaitu kanon, yang sudah diterima dan dipelajari dari generasi ke generasi secara tradisional. Di sisi lain terdapat seperangkat teori tentang karya itu sendiri, tentang apa sastra itu, bagaimana mengadakan pendekatan terhadap karya sastra, dan tentang watak serta pengalaman manusia yang ditulis dan dijelaskan dalam karya sastra.

Karya sastra tersebut sebagai salah satu bentuk representasi budaya yang menggambarkan nilai-nilai yang dimiliki oleh masyarakat yang terdapat di sekitar pengarang, atau bahkan merupakan kenyataan sosial budaya masyarakat yang melingkupi pengarangnya. Kenyataan tentang persoalan sosial tersebut disebabkan karena adanya ketimpangan dalam masyarakat.

Para pengarang karya sastra di Indonesia pada awal tahun 1920-an atau yang dikenal dengan angkatan Balai Pustaka, didominasi oleh laki-laki banyak menciptakan karya-karya yang umumnya menceritakan kehidupan tokoh perempuan. Para tokoh perempuan ini selalu mengalami penderitaan yang sebagian besar dikarenakan ketidakberdayaan mereka terhadap aturan-aturan tradisi yang telah melekat erat pada sebagian besar masyarakat di Indonesia. Kelemahan ini bahkan tidak jarang berujung pada kematian. Meskipun ada beberapa karya sastra yang mulai menunjukkan emansipasi perempuan seperti karya Sutan Takdir Alisyahbana pada tahun 1930-an yaitu pada novel Layar Terkembang yang mulai membangkitkan semangat dengan menyadarkan para perempuan yang selama ini mengalami ketertindasan (Rani,1997: 91).

Semangat pembelaan perempuan dalam novel-novel Balai Pustaka selaras 
dengan perjuangan feminisme. Perjuangan feminisme dan tokoh-tokoh perempuan dalam novel berusaha memperjuangkan hak-haknya. Mereka berpendapat bahwa kelemahan dan kebodohan perempuan bukan karena kodrat, melainkan karena tidak dibiasakan dan tidak diberi kesempatan yang sama dengan laki-laki. Penokohan perempuan dapat menjadi corong bicara pengarang dalam meneriakkan emansipasi dan protes terhadap tradisitradisi kaku yang membelenggu mereka, terhadap kesewenang-wenangan kaum laki-laki.

Salah satu novel modern di Indonesia yang menggambarkan tentang kehidupan wanita adalah novel Cinta Di Ujung Sajadah. Novel ini merupakan karya Asma Nadia. Pemilihan novel Cinta Diujung Sajadah sebagai objek penelitian didasarkan pada beberapa hal. (1) Cinta adalah seorang anak piatu yang mulai kecil tidak pernah tau siapa ibunya. Cinta Diujung Sajadah merupakan novel yang berisi perjuangan perempuan yang selalu berupaya mempertahankan harkat, martabat, dan derajat kaum perempuan, (2) Novel ini mengangkat eksistensi perempuan, pokok-pokok pikiran feminisme, dan nilai pendidikan.

\section{METODE PENELITIAN}

Mengkaji karya sastra dengan menggunakan pendekatan feminisme ini termasuk penelitian jenis kualitatif. Data yang diperoleh dari penelitian ini merupakan data verbal, yaitu paparan bahasa dari pernyataan tokoh yang berupa dialog dan monolog, serta narasi yang ada dalam novel Cinta Di Ujung Sajadah Karya Asma Nadia Instrumen yang digunakan dalam penelitian ini adalah peneliti sendiri. Metode kualitatif merupakan prosedur penelitian yang menghasilkan data deskriptif berupa kata- kata tertulis atau lisan dari orang-orang dan pelaku yang dapat diamati.

Berdasarkan uraian di atas kajian novel Cinta Di Ujung Sajadah Karya Asma Nadia merupakan penelitian kualitatif yang mengkaji gambaran feminisme dan nilai pendidikan dalam novel Cinta Di Ujung Sajadah Karya Asma Nadia Penelitian ini merupakan penelitian kualitatif dengan studi pustaka dan tidak terikat dengan tempat penelitian.

\section{HASIL PENELITIAN}

Novel Cinta di Ujung Sajadah karya Asma Nadia banyak menggambarkan perempuan dalam dunia patriarki sebagai the second sex. Kondisi seperti itu digambarkan pada tokoh Ayuningsih, menjadi korban perlakuan suami hidung belang. Ayu yang hidup di dunia malam yang bekerja sebagai pelacur di wisma cantik, kembang malam hal ini dibuktikan dengan kutipan sebagai berikut "ayuningsih pelacur itu”?

"saya ndak mungkin lupa ayuningsih yang paling top! Hahaha ..." (Asma Nadia :204)

Dengan latar belakang itu suami ayuningsih marah dan Ayu akhirnya memilih pergi meninggalkan suami dan anaknya.

Setelah itu suaminya menikah dengan Mama Alia. Tetapi Ayahnya ternyata tidak berubah. Ayahnya selalu bersikap tidak adil. Hal ini diperkuat dengan kutipan berikut:

"nggak apa mbok, kalau nggak ada yang membela biar saya yang membela diri saya sendiri, ya kan pa?". (Asma Nadia, 2015:40).

Cinta ayu tetap memilih tinggal dengan ayahnya meskipun dia tidak ada yang melindungi, apalagi dengan sikap ayahnya yang cuek terhadap perlakuan anak tirinya yang dilakukan pada cinta ayu, meskipun hatinya sakit. Ia harus terima ketika disakiti dua saudara tiri dan mama Alia. Bahkan ayahnya malah membela saudara tirinya tanpa 
mengetahui masalah yang sebenarnya, sebagai mana kutipan berikut:

"Cinta Cuma merasa harus membela diri pa selama ini kan memang nggak ada yang berbaik hati membela cinta " (Asma Nadia, 41)

\section{Kekerasan terhadap Perempuan}

Penetapan Undang-Undang itu diharapkan mampu memberi perlindungan hukum bagi perempuan yang menjadi korban tindak kekerasan dalam rumah tangga. Sugihastuti dan Itsna Hadi Saptiawan (2007: 173-176) menjelaskan bahwa kekerasan terhadap perempuan meliputi kekerasan domestik dan kekerasan publik. Kekerasan domestik adalah kekerasan yang dilakukan oleh orang-orang yang dekat dengan korban, seperti orang tua, kakak, adik, suami.

Sedangkan kekerasan publik merupakan kekerasan di ruang publik biasanya dilakukan oleh tetangga, teman, kerabat, sepupu, bahkan saudara kandung. Adapun bentuk kekerasan dalam rumah tangga (KDRT) seperti yang disebut di atas dapat dilakukan suami terhadap anggota keluarganya dalam bentuk : 1) kekerasan fisik, 2) kekerasan psikis, 3) kekerasan seksual, 4) penelantaran rumah tangga yang terjadi dalam lingkup rumah tangganya.

Uraian di atas sesuai dengan UU RI No. 23 tahun 2004 tentang penghapusan KDRT, pada pasal 5 disebutkan bahwa setiap orang dilarang melakukan kekerasan dalam rumah tangga terhadap orang dalam lingkup rumah tangganya, dengan cara; kekerasan fisik, kekerasan psikis, kekerasan seksual atau penelantaran rumah tangga. 1) Kekerasan Fisik Pasal 6 UU RI No. 23 tahun 2004 tentang penghapusan KDRT menyebutkan bahwa kekerasan fisik merupakan perbuatan yang mengakibatkan rasa sakit, jatuh sakit, atau luka berat.

\section{Cinta Ayu}

Cinta ayu sering dipandang sebelah mata oleh ayahnya dan saudara tirinya. Bahkan setiap ada pertengkaran antara cinta dengan saudaranya pasti ayahnya membela saudara tirinya karena ayahnya tidak mau mendengarkan penjelasan dari cinta. meskipun yang dilakukan itu merupakan perbuatan yang terpuji. Hal ini semata-mata karena Cinta ayu adalah seorang anak yang bekerja sebagai tukang pijat. Ayuningsih seorang tukang pijat didaerah pelacuran,

" hus gak boleh fitnah begitu. Dia kan Cuma tukang urut."(Asma Nadia : 204)

Seorang tukang pijat di daerah pelacuran. Dulu hampir semua orang mencibirkan bibir. Banyak tuduhan keji dialamatkan kepada dirinya. Ia nyaris putus asa ketika tuduhan itu Hinaan yang diterima cinta merupakan bentuk kekerasan emosional karena menimbulkan rasa marah, sakit hati, dan kecewa. Ayuningsih merasa sakit hati terhadap orang-orang yang sama sekali tidak pernah disakiti olehnya.

\section{Ayuningsih}

Ayuningsih adalah seorang mantan pelacur yang telah jatuh cinta pada seorang laki-laki yang kini menjadi suaminya, akan tetapi itu tidak berlangsung lama karena seseorang telah membongkar rahasianya dan suaminya ndak mau tahu karena merasa dibohongi.

\section{Mbok Nah}

Adalah pembantu dirumah cinta yang sebelum cinta lahir sudah berada di rumah itu dan selalu menjaga cinta dengan kasih sayangnya tidak ada yang memberi kasih sayang terhadap cinta kecuali mbok nah.

\section{Makky}

Makky adalah sosok laki laki yang sederhana dia tidak memiliki ayah yang kini tinggal didepan rumah cinta dan 
makki termasuk laki laki yang tergolong oke, makki adalah seseorang yang selalu ada buat cinta selain mbok nah.

\section{Perlawanan Perempuan}

Kekerasan dan penindasan yang terjadi terkadang menimbulkan perlawanan dari pihak yang tertindas. Dalam novel Cinta diujung Sajadah Karya Asma Nadia, perlawanan perempuan digambarkan pada tokoh Cinta. Cinta merupakan sosok yang santun, bijaksana, pemaaf tetapi tegas. Penderitaan yang ia alami menjadikannya perempuan yang tegar. Cinta mampu membebaskan diri dari usaha dari rahasia yang dilakukan oleh ayahnya. Perlawanan itu dibuktikan dengan usahanya dalam mempertahankan rumah singgah. Perlawanan perempuan lain ditunjukkan melalui tokoh ayuningsih.

\section{Tokoh Profeminis dan Kontrafeminis Tokoh Profeminis \\ Cinta}

Tokoh profeminis merupakan tokoh yang mendukung kegiatan kegiatan feminisme. Cinta, tokoh perempuan dalam novel Cinta diujung Sajadah karya Asma Nadia merupakan tokoh profeminis. Ia tidak bergantung kepada siapapun. Cinta sudah mantap dengan pilihannya untuk Mencari ibunya yang membelenggu eksistensinya, meskipun hidup sendirian. Cinta tetap berusaha membuktikan bahwa dia bisa hidup sendiri. Tokoh Cinta merupakan gambaran tokoh profeminis. Cinta berusaha keras untuk menemukan ibunya sendiri.

\section{Tokoh Kontrafeminis Cantik}

Cantik merupakan tokoh yang membenci Cinta karena merasa Cinta pernah mengecewakannya. Cinta tidak mau sejalan dengannya. Cantik selalu berusaha menghancurkan Cinta, selain dengan memfitnah dan mencari gara gara. Cantik benar-benar menyimpan dendam terhadap Cinta. Hal ini diperkuat dengan kutipan berikut:

“Eh gak punya mulut ya? “( Asma Nadia : 39)

\section{Anggun}

Dalam novel Cinta diujung Sajadah karya Asma Nadia, terdapat tokoh perempuan yang menindas perempuan dan sering menyakiti hati perempuan. Gambaran itu terdapat pada tokohAnggun.

\section{Mama Alia}

Mama Alia, istri ke dua ayahnya cinta. Ia berani dalam mengambil tindakan sendiri dia selalu bersama anak nya. Dia tidak berani mengambil keputusan yang dapat mengangkat persamaan derajat dengan kaum laki-laki. Dia menggambarkan sebagai sosok perempuan lemah yang bergantung pada laki-laki.

\section{Feminisme Sosial}

Feminisme sosialis memandang ketertindasan perempuan terjadi akibat adanya sistem kelas dan manifestasi ketidak adilan gender yang merupakan konstruksi sosial dalam masyarakat. Feminisme sosialis menganggap bahwa penindasan perempuan tersebut di atas karena adanya budaya patriarki dan sistem kapitalisme.

\section{Nilai Pendidikan}

Karya sastra pada dasarnya selalu mengandung nilai-nilai kehidupan yang bermanfaat untuk pembaca. Muatan nilainilai yang tersirat dalam karya sastra pada umumnya adalah nilai religius, nilai moral, nilai sosial, nilai estetika, dan adat/budaya. 


\section{Nilai Pendidikan Agama}

Nilai religius (agama) dalam sebuah karya sastra merupakan peneguh batin bagi pembacanya, termasuk di dalamnya yang bersifat keagamaan. Hubungan Manusia dan Tuhan mencerminkan nilai keagamaan manusia. Nilai agama yang terwujud dari perilaku dan pembicaraan dituangkan Asma Nadia melalui tokoh-tokoh yang ada dalam novel Cinta diujung Sajadah karya Asma Nadia Agama dalam novel ini adalah agama sebagai keyakinan tokoh cerita,bukan agama yang dipermasalahkan. Jadi unsur agama yang muncul tidak menimbulkan terjadinya konflik. Lewat tokoh Cinta dapat dapat diketahui bahwa novel Cinta diujung Sajadah karya Asma Nadia mengandung pesan agama agar kita selalu ingat kepada Tuhan. Cinta adalah seorang perempuan sekaligus ibu yang senantiasa menyebut nama Tuhan setiap kali akan menjalankan pekerjaannya. Hal ini diperkuat dengan kutipan berikut Cinta mengusapkan minyak sere ke punggung laki-laki muda yang berbaring).

\section{Nilai Pendidkan Moral}

Nilai moral mencerminkan pandangan hidup seseorang. Nilai moral merupakan pandangan hidup tentang nilai-nilai kebenaran. Perilaku moral dikendalikan oleh konsep moral, yakni aturan-aturan dalam bertingkah laku sesuai dengan pola perilaku yang diharapkan oleh masyarakat. Karya fiksi juga merupakan sarana bagi pengarang untuk menyampaikan pesan moral. Fiksi mengandung penerapan moral dalam sikap dan tingkah laku para tokoh sesuai pendangan pengarang tentang moral. Melalui peristiwa yang disuguhkan dalam alur cerita serta tingkah laku tokoh-tokoh yang terdapat dalam novel, pembaca diharapkan dapat mengambil hikmah dari pesan-pesan moral yang disampaikan.
Nilai moral dalam novel Cinta diujung Sajadah karya Asma Nadia begitu jelas tergambarkan dalam alur cerita. Nilai moral yang berupa hubungan cinta kasih antara ibu dengan anak kandung dan anak asuhnya juga dapat terbaca dengan jelas. Cinta mendidik anaknya melakukan pekerjaan yang halal. Cinta selalu mendidik anak-anaknya dengan memberikan nasihat, agaranak-anaknya senantiasa bermoral tinggi. Perhatian yang diberikan Cinta kepada Taufik merupakan pesan moral yang patut dicontoh. Pesan moral yang terkandung dalam novel Cinta diujung Sajadah karya Asma Nadia adalah sebagai berikut: 1) agar manusia tidak korupsi, karena korupsi sama ssaja mencuri harta rakyat; 2) manusia tidak boleh beranggapan bahwa semua tukang pijat bermoral rendah; 3) manusia tidak boleh memandang rendah pekerjaan halal yang lain Melalui tokoh Cinta dan Taufik pesan-pesan moral tersebut disampaikan agar pembaca dapat mengambil hikmah dari cerita tersebut.

\section{Nilai Pendidikan Sosial}

Nilai sosial terlihat dari penggambaran kehidupan masyarakat. Manusia adalah makhluk sosial yang saling membutuhkan. Manusia tidak akan mampu hidup sendiri. Sebagai makhluk sosial manusia akan selalu berinteraksi dengan orang lain. Oleh karena itu hubungan antara manusia dengan manusia lain harus terjalin dengan baik, meskipun seringkali sifat mengutamakan kepentingan pribadi muncul.

Di dalam novel Cinta diujung Sajadah karya Asma Nadia nilai pendidikan sosial digambarkan melalui dialog antar tokoh di dalamnya. Nilai tersebut terwujud dalam bentuk membantu orang lain yang membutuhkan. Cinta dalam keterbatasannya masih berbesar hati mau 
mengurus anak-anak terlantar di rumah singgah. Ttidak terlalu luas itu Cinta mengajara nak-anak mengaji. Nilai pendidikan sosial yang dapat diperoleh dari novel Cinta diujung Sajadah karya Asma Nadiayaitu: 1) manusia hendaknya mau melakukan sesuatu untuk orang lain yang lebih membutuhkan. Bantuan itu tidak hanya berwujud uang atau benda, tetapi bisa juga berbentuk perhatian.; 2) manusia harus peduli dengan lingkungan.

\section{SIMPULAN}

Simpulan yang diperoleh dari penelitian ini adalah sebagai berikut.

1. Eksistensi Perempuan dalam Novel Cinta di Ujung Sajadah karya Asma Nadia adalah:

a) Perempuan dalam dunia patriarki sebagai the second sex.Hal ini terlihat dari cerita tentang perlakuan suami kepada istrinya.Meskipun sang istri sudah cantik, setia suami merasa belum puas. Suami memilihmelakukan menikah lagi.

b) Kekerasan terhadap perempuan meliputi kekerasan fisik, kekerasan seks, dan kekerasan psikis.

c) Kebebasan menentukan pasangan hidup terlihat pada sosok cinta ayu yang memilih untuk mencari ibunya karena tidak mau dibohongi.

d) Perlawanan perempuan berbentuk perlawanan fisik.

2. Pokok-pokok pikiran feminisme dalam novel Cinta di Ujung Sajadah karya Asma Nadia meliputi:

a) Tokoh perempuan mampu membuktikan bahwa perempuan tidak selalu bergantung kepada laki laki.

b) Tokoh profeminis adalah tokohtokoh yang mendukung perjuangan feminisme, kebalikannya tokoh kontrafeminis berusaha untuk menentang perjuangan feminisme.

c) Feminisme sosial tampak pada usaha perempuan untuk menentang perlakuan tidak adil atasannya. Pekerja perempuan berusaha menjaga diri dari pelecehan yang dilakukan atasan. Bahkan perempuan sanggup menerima akibat dari tindakannya, misalnya setelah dipecat dari pekerjaan perempuan mampu bekerja lagi sesuai pilihannya.

\section{DAFTAR PUSTAKA}

Pasal 6 UU RI No. 23 tahun 2004 penghapusan KDRT menyebutkan bahwa kekerasan fisik merupakan perbuatan yang mengakibatkan rasa sakit, jatuh sakit, atau luka berat.

Ratna, Nyoman Kutha,2011. Perempuan dengan kelemahan-kelemahannya secara biologis selalu ditempatkan sebagai inferior atau kaum yang tertindas.Jakarta : Balai Pustaka

Saptiawan, Itsna Hadi, dan Sugihastuti, 2007 menjelaskan bahwa kekerasan terhadap perempuan meliputi kekerasan domestik dan kekerasan publik.

Sugihastuti, Itsna Hadi Saptiawan. 2007. Kekerasan terhadap Perempuan. Jakarta: PT Gramedia.

Suwardi, Endraswara,2011Keinginan perempuan untuk menemukan eksistensinya. Jakarta: Balai Pustaka

UU RI No. 23 tahun 2004. Penghapusan KDRT. 